DOI 10.37882/2223-2982.2020.12.11

\title{
ОСНОВНЫЕ ПРИНЦИПЫ ОБУЧЕНИЯ ЛЕКСИКЕ ФРАНЦУЗСКОГО ЯЗЫКА КАК ВТОРОГО ИНОСТРАННОГО ПРИ ПЕРВОМ АНГЛИЙСКОМ СТУДЕНТОВ ВУЗА
}

\section{BASIC PRINCIPLES OF TEACHING FRENCH VOCABULARY AS A SECOND FOREIGN LANGUAGE TO UNIVERSITY STUDENTS LEARNING ENGLISH AS A FIRST FOREIGN LANGUAGE}

\section{E. Efremova \\ M. Efremova}

Summary: The present article is devoted to the problem of teaching French as a second foreign language to university students learning English as a first foreign language. Special attention is paid to teaching French vocabulary. The author of the article suggests to organise second foreign language classes on the basis of the general methodological principles: the principle of differentiated approach in teaching; the principle of setting concrete targets; the principle of the supervision of the educational process; the principle of the complex approach to motivation in teaching foreign language. General methodological principles are regarded as standing rules of teaching foreign languages, lexical aspect of the language in particular. The author of the article identifies the main difficulties that Russian-speaking students face in mastering vocabulary in a context of trilingualism and suggests how to overcome them. The article includes samples of tasks aimed at developing lexical habits.

Keywords:second foreign language, trilingualism, general methodological principles, teaching vocabulary, lexical habit.

\section{Ефремова Екатерина Михайловна}

к.филол.,н., доцент, Московский педагогический государственный университет, г.Москва

ECatherine1@yandex.ru

Ефремова Марина Владимировна к.n.н., дочент, Московский педагогический государственный университет, г.Москва

EMarine@yandex.ru

Аннотация: Данная статья посвящена проблеме обучения лексике французского языка как второго иностранного при первом английском студентов языкового вуза. Обучение французской лексике на занятиях по второму иностранному языку предлагается строить на основе общих методических принципов: принципа дифференцированного подхода в обучении, принципа выделения конкретных ориентиров, принципа управления процессом обучения, принципа комплексного подхода к мотивации в обучении иностранному языку. Общие методические принципы рассматриваются как постоянно действующие закономерности обучения иностранному языку, в частности лексическому аспекту языка. Выявлены основные трудности, возникающие у русскоязычных учащихся в процессе овладения лексикой в условиях трилингвизма, и предложены пути их преодоления. Приведены примеры заданий, направленных на формирование иноязычных лексических навыков.

Ключевые слова: второй иностранный язык, трилингвизм, общие методические принципы, обучение лексике, лексический навык.
B современном мире, в эпоху интеграции во всех областях деятельности человека, владение только одним иностранным языком становится явно недостаточным. В системе высшего образования все больше внимания уделяется изучению двух и более иностранных языков. Успешное решение коммуникативных задач в иноязычной среде возможно при условии владения участниками коммуникации лексикой языка общения. Лексика, как словарный состав языка, является ведущим компонентом речевого общения, выступает в речи во взаимодействии с фонетикой и грамматикой. Овладение лексикой второго иностранного языка в условиях трилингвизма, т.е. при контакте родного языка и двух иностранных языков, представляет трудность в теории и на практике.

В настоящее время отсутствует единая общепринятая классификация методических принципов обучения ино- странному языку. Принципы обучения основному иностранному языку, выделяемые учеными-методистами, отличаются от принципов обучения второму иностранному языку. В свою очередь, это осложняет деятельность преподавателя в плане подготовки и проведения занятий по языку. Классификация методических принципов, предложенная Р.К. Миньяр-Белоручевым, на наш взгляд, носит универсальный характер и актуальна как для процесса обучения основному, так и второму иностранному языку. Выделяются следующие общие методические принципы: принцип дифференцированного подхода в обучении, принцип выделения конкретных ориентиров, принцип управления процессом обучения, принцип комплексного подхода к мотивации в обучении иностранному языку [5, с. 26]. Рассмотрим на конкретных примерах реализацию вышеназванных принципов в процессе обучения студентов лексике французского языка как второго иностранного при первом англий- 
CKOM.

Принцип дифференцированного подхода в обучении представляет собой развитие важнейшего дидактического принципа доступности и посильности, отражает реально существующее многообразие целей и условий обучения. Данный принцип реализуется в двух направлениях.

С одной стороны, учитываются общие возрастные особенности и способности учащихся. Студенты, приступающие к изучению второго иностранного языка, обладают значительным лингвистическим опытом в изучении первого иностранного языка, в использовании разных стратегий учения. Б.В. Беляев отмечает, что «если при овладении первым иностранным языком человек с большим трудом начинает улавливать лексическое и грамматическое своеобразие двух языков (родного и иностранного), то при овладении вторым иностранным языком он уже наперед чувствует возможное своеобразие этого языка и поэтому легче схватывает как его лексические, так и грамматические особенности» [1, с.22]. Изучающие второй иностранный язык характеризуются высоким уровнем «обучаемости» [4].

С другой стороны, учитывается неоднородность лексических единиц, т.е. единиц языка, способных выполнять функции единиц речи. Лексическая единица может быть представлена словом, устойчивым словосочетанием, готовой фразой. Лексические единицы дифференцируются по частям речи, относятся к разным функциональным стилям. Французские и английские слова, совпадающие по форме (преимущественно графической) и значению, усваиваются путем положительного переноса: франц. attention (f), page (f), exercice (m) / англ. attention, page, exercise. При изучении слов, совпадающих или практически совпадающих по форме, но отличающихся по значению, следует учитывать возможность возникновения межъязыковой лексической интерференции. Речь идет о так называемых «ложных друзьях переводчика», например:

франц. demander - англ. ask / франц. exiger - англ. demand;

франц. librairie (f) - англ. bookshop / франц. bibliothèque (f) - англ. library;

франц. lecture (f) - англ. reading / франц. conférence (f) - англ. lecture.

Неоднородность лексического материала обуславливает использование разных приемов обучения.

Принцип выделения конкретных ориентиров, являясь развитием дидактического принципа наглядности, заключается в выделении хорошо известных объектов в качестве ориентиров, определяющих и стимулирующих последовательные речевые действия учащихся. Идея использовать ориентиры в обучении положена в основу теории поэтапного формирования умственных действий П.Я. Гальперина [2]. При выделении конкретных ориентиров следует учитывать уровень обученности учащихся, а также характер языкового материала. Например, при знакомстве с новой лексикой выявляются трудности, связанные с формой лексических единиц. Велико значение конкретных ориентиров в обучении графической форме французских слов. При изучении accents во французском языке, явлении, не имеющем аналогов в русском и английском языках, можно выделить следующие ориентиры: Accents над е не ставится в сочетаниях букв:

*e+x (lexique, flexible);

*е+удвоенная согласная (effacer, lettre);

*е+конечная согласная, -ые (cher, aspect), кроме незначительных исключений.

Отметим: данные конкретные ориентиры имеют теоретическое обоснование в виде общего правила постановки accents во французском языке, которое заключается в том, что accents возможен лишь в графически открытом слоге [3].

Для усвоения звуковой формы французских слов важным является ориентир, связанный с ударением в слове. Во французском языке, в отличие от русского и английского языков, в отдельно взятом слове ударение всегда падает на последний произносимый слог. Запомнить удлиняющие согласные звуки [r], [z], [v], [3], перед которыми любой гласный звук под ударением становится долгим, поможет ориентир в виде словосочетания: розовый еж.

Принцип управления процессом обучения является развитием дидактического принципа систематичности, последовательности, прочности усвоения.

Обучение лексике связано с формированием лексических навыков и осуществляется поэтапно. Семантизация новой лексики, раскрытие значения, предполагает последовательное становление системы денотативных, знаковых, ситуационных, семантических, сигнификативных и фоновых связей лексической единицы [5].

Денотативная связь, т.е. связь лексической единицы с денотатом, объектом действительности. Указывая на предмет, лицо, явление, и называя его на иностранном языке, мы устанавливаем денотативную связь лексической единицы. Денотативные связи лежат в основе беспереводного способа семанизации лексики. Знаковые связи - это связи лексической единицы изучаемого языка и ее эквивалентом (квазиэквивалентом) в родном и/или первом иностранном языке: франц. ordinateur 
(m) - русск. компьютер - англ. computer. Знаковые связи лежат в основе переводного способа семантизации лексических единиц. Важно отметить, что вопрос о доминировании первого иностранного языка или родного языка в условиях трилингвизма все еще остается открытым. В процессе становления ситуационных связей лексической единицы определяется речевая ситуация, в которой принято ее употребление, например: voyageur (m) - пассажир, в основном поезда / passager (m) - пассажир самолета, парохода, машины. Или еще один пример: être malade - быть больным, часто тяжело / для обозначения легкого недомогания используются выражения être souffrant(e), se sentir fatigué(e). Семантические связи, т.е. связи лексической единицы с другими лексическими единицами, входящими в одну семантическую систему, тематически объединенную группу слов. Традиционно членение лексического материала на дозы осуществляется в соответствии с разговорными темами учебника. Например, в рамках темы «Еcole» изучаются лексические единицы, обозначающие учебные предметы, виды деятельности учителя и учащихся, названия предметов в классе, формулы классного обихода и т.д. Наблюдения показывают, что слова, сгруппированные по темам, запоминаются легче, чем слова, не объединенные тематическим единством. Сигнификативная связь представляют собой связь лексической единицы с понятием. Так например, понятие «стол» (предмет мебели) охватывает его реально существующие виды, такие как: table (f) de cuisine, table (f) de jardin, table (f) gigogne, table (f) pliante, bureau $(m)$, table $(f)$ de jeu, guéridon $(m)$, pupitre $(m)$ и т.д.. Возникновению сигнификативных связей предшествуют денотативные связи, т.е. осуществляется переход от конкретного к абстрактному. И наконец, фоновые связи - ассоциации национально-культурного характера, возникающие в связи с новой лексической единицей, например, касающиеся нумерации этажей в доме или обозначения времени суток. Французское слово rez-dechaussée (m) ассоциируется с английским ground floor первый этаж. Соответственно словосочетание maison (f) sans étages (букв. дом без этажей) означает: одноэтажный дом. Французское выражение deux heures du matin соответствует английскому two o'clock a.m. (two o'clock in the morning) - два часа ночи.

Организация тренировки в процессе формирования лексических навыков на занятиях по второму иностранному языку имеет целью закрепление установленных связей новых лексических единиц и мало чем отличается от соответствующей тренировки при обучении лексике первого иностранного языка. Обычно тренировка начинается с рецептивных упражнений, например: узнавание новых слов в тексте для чтения / аудирования; упражнения с синонимами / антонимами и др. Затем выполняются репродуктивные упражнения, например, вопросно-ответные. При работе с лексикой второго ино- странного языка особую роль играют межъязыковые контрастирующие упражнения, например:

- Найдите различия во французских и английских словах и сформулируйте правило трансформации.

- Соедините французские и английские слова, выражающие одно понятие и др.

Совершенствование лексических навыков завершается на этапе речевой практики, предусмотренной для различных видов речевой деятельности: аудирования, говорения, чтения, письма. Понятие управления процессом обучения включает систематическое повторение пройденного, организацию контроля и самоконтроля.

Принцип комплексного подхода к мотивачии в обучении иностранному языку представляет собой развитие дидактического принципа активности. Мотивация рассматривается как «система побудительных причин человеческого поведения, источник активности, организующий и направляющий деятельность человека» [6, с.57]. Применительно к процессу обучения второму иностранному языку в вузе можно говорить о взаимодействии нескольких разновидностей мотивации. Коммуникативная мотивация основана на стремлении студентов общаться с носителями языка в устной и письменной форме. Инструментальная мотивация связана с необходимостью использования языка в последующей деятельности, например учебе или работе. Познавательная мотивация основана на потребности расширения общего кругозора, увеличении знаний о стране изучаемого языка. Вызов эстетической мотивации определяется стремлением изучать иностранный язык для удовольствия, получаемого, например, от мелодичности звучащей речи.

Данный принцип учитывает многообразие стимулов, побуждающих к работе над иностранным языком. К таким стимулам относятся: наличие речевой перспективы, аутентичный лексический материал, учет межпредметных связей, разные режимы работы (индивидуальные и коллективные) на занятиях и др. Чтобы вызвать интерес, создать у студентов ощущение достигнутого успеха сокращается временной разрыв между ознакомлением с новой лексикой и ее применением в речи. С самых первых занятий усваиваются коммуникативно полезные фразы, микродиалоги, позволяющие осуществлять речевую деятельность. Отбор лексики играет важную роль в достижении аутентичности высказывания. В процессе обучения студенты знакомятся с аутентичной лексикой разнообразной по тематике и принадлежащей к разным стилям речи. С этой целью используются устные и письменные тексты зарубежных авторов - носителей языка.

Традиционно в практике обучения студентов французскому языку как второму иностранному используют- 
ся те же учебники, что и при обучении французскому как первому иностранному языку. Соответственно не учитывается мотивационный потенциал соизучения двух иностранных языков. Слова второго языка у обучающихся связываются не с системой понятий, а со словами родного языка, что характерно для несвободного владения языком. Работа над новой лексикой второго иностранного языка должна включать упражнения по сопоставлению родного, первого иностранного и второго иностранного языка, в том числе переводные упражнения, формирующие навык переключения с одного языка на другой. Стимулы, обеспечивающие вызов мотивации, можно варьировать в зависимости от интересов, уровня обученности учащихся, а также характера учебного материала.

В заключение отметим, что комплексная реализация рассмотренных в статье принципов на занятиях по второму иностранному языку позволяет повысить эффективность процесса обучения лексическому аспекту языка. Применяя методические приемы и упражнения с учетом специфики обучения в условиях трилингвизма, преподаватель закладывает у студентов основы владения языками в равной степени, что, в свою очередь, отвечает потребности общества в специалистах, всесторонне владеющих иностранными языками.

ЛИТЕРАТУРА

1. Беляев Б.В. Очерки по психологии обучения иностранным языкам. М.: Просвещение, 1965. -227 с.

2. Гальперин П.Я. Развитие исследований по формированию умственных действий // Психологическая наука в СССР. Т.1. М.: Изд-Во АПН РСФСР, 1959. C. 441-469.

3. Ефремова М.В. Методика обучения узуальной орфографии французского языка в языковом вузе: автореф. дис. ... канд. пед. наук: 13.00 .02 / Московский пед. гос. ун-т. М., 1999. 16 с.

4. Лапидус Б.А. Обучение второму иностранному языку как специальности. М.: Высшая школа, 1980. - 173 с.

5. Миньяр-Белоручев Р.К. Методика обучения французскому языку. М.: Альянс, 2012. - 224 с.

6. Миньяр-Белоручев Р.К. Методический словник. Толковый словарь терминов методики обучения языкам. М.: Стела, 1996. - 144 с.

( Е Ефремова Екатерина Михайловна (ECatherine1@yandex.ru), Ефремова Марина Владимировна (EMarine@yandex.ru).

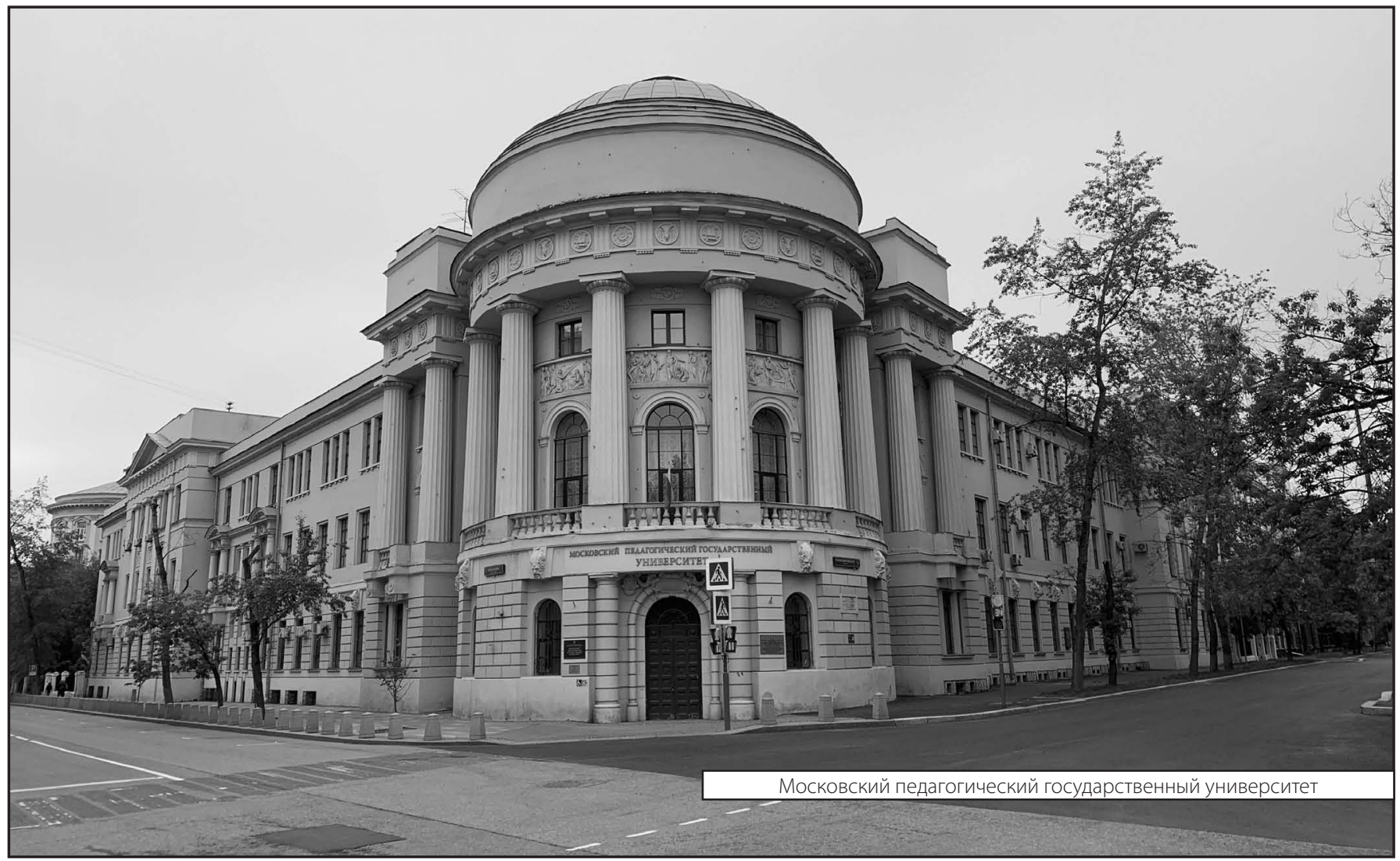

